\title{
Algumas confusões, num severo ataque à intelectualidade
}

GERARD LEBRUN

Decididamente, Roberto Schwarz tem muito talento. Não sei se a sua destreza em distribuir cacetadas à direita e alfinetadas à esquerda fascinará ou irritará os leitores, mas estou certo de que não se aborrecerão um só instante com as suas duas últimas coletâneas de ensaios'. Deixo a alguém mais competente o encargo de julgar o seu estudo sobre Machado de Assis, e criticar quanto ao fundo as Idéias fora do Lugar. A mim, esta última análise - nervosa e densa parece-me o modelo do que deveria ser a sociologia da cultura. Sem sombra de pendantismo, Schwarz faz-nos refletir sobre um desses fenômenos de transplante ideológico sem os quais não seria possível compreender as contradições da cultura brasileira de hoje - nem a sua riqueza.

A "riqueza", é verdade, quem acrescenta sou eu. Pois não consigo compartilhar a severidade de Schwarz em relação à cultura seja porque sou menos maldoso, seja porque sou menos marxista que ele... E até me pergunto se esta propensão a desmistificar alegremente os fenômenos de cultura nacional não constitui um traço característico da crítica de idéias brasileiras (sejam quais forem os artigos de acusação: seqüela da herança colonial, ideologia importada, ideologia burguesa mal camuflada...). Vejam por exemplo o livro recente em

1. Roberto Schwarz: O Pai de Familia e outros estudos (ed. Paz e Terra); Ao Vencedor as Batatas (ed. Duas Cidades). 
que, com virtuosismo, mas também com vitríolo, Caio Toledo varre a ideologia do ISEB. Ou ainda as maldades que aparecem regularmente nas gazetas acerca de Jorge Amado ou Gilberto Freyre (a tal ponto que as jovens geraçð̃es - reparei - ignoram mui simplesmente a importância que tiveram estes autores). "Integre, cara Ângela, integre", recomendava o velho Gide, perito em classicismo. No Brasil, a palavra de ordem seria antes: "Façamos tábua rasa do passado" - vejamos quem "desintegrará" mais corrosivamente.

"Vista ao microscópio, dizia Espinosa, a mais bela mão pode parecer horrivel." No microscópio de Schwarz, boa parte da produção cultural brasileira aparece como um suspeito emaranhado ideológico. Quando se trata de descrever a aberrante transplantação do "liberalismo" europeu para um país ainda escravagista (As Idéias fora do Lugar), o método funciona às maravilhas. Parece-me mais duvidosa a sua pertinência quando o autor empreende analisar Cultura e Política: 1964-1969. É verdade que nos previne, em nota preliminar, que o ensaio foi escrito em 1969-70, e que honestamente o publica sem nada alterar. Trata-se pois de um texto do "jovem Schwarz", da sua "Ideologia Brasileira". Mas, já que não o abandonou à "crítica roedora dos ratos", fica o leitor autorizado a julgá-lo tal como aparece.

Vista em 1969-70, esta década de 1960 já aparecia como os "bons velhos tempos". E algumas pequenas notas stendhalianas deixam transparecer a emoção que o autor sente ao evocar essa época: "O Pais estava irreconhecivelmente inteligente. $\mathrm{O}$ jornalismo político dava um extraordinário salto nas grandes cidades, bem como o humorismo. Mesmo alguns deputados fizeram discursos com interesse". Impossivel não compartilhar esta nostalgia, para quem viveu os anos 60-64 com os intelectuais paulistas. Mas o autor, é claro, passa bem rapidamente pela saudade. Tenta compreender como essa "intelligentsia" pôde cometer erros tão graves de prognóstico: despreocupada, febril, provocadora, ela não pressentia a ascensão dos perigos... E Schwarz nos mostra como era confusa a sua ideologia, e ingênuas as suas certezas (a "burguesia nacional", a união sagrada contra o latifúndio e o imperialismo, etc...). A sua intenção, porém, é fazer sociologia cultural. O que the interessa é a sensibilidade da "intelligentsia" de 1964 a 1969, e a ambigüidade da sua situação: a um tempo ligada às classes dominantes, e "abcesso" no seio destas. Como criticar a sério um sistema de valores, quando se vive sob a proteção do sistema econômico que o engendra? Esta é a questão que preocupa o autor - e à qual responde sem a menor complacência.

Assim, quando tenta emitir um juizo eqüitativo sobre o teatro da 
época, é a severidade que acaba por prevalecer. A dar-lhe crédito, o repertório do Teatro de Arena, que refletia apenas "um momento ainda incompleto da crítica ao populismo", não conseguiu fazer surgirem "os verdadeiros temas do teatro político". Ainda mais duro é o juizo sobre a obra do Teatro Oficina, cujo radicalismo estético é porém analisado com simpatia. Afinal de contas, "instalando-se no descampado que é hoje a ideologia burguesa, o Oficina inventa e explora jogos apropriados ao terreno, torna habitável, nauseabundo e divertido o espaço do niilismo após 64. Como então afirmar que este teatro conta à esquerda?" - Não é esta uma maneira algo expedita de tratar um movimento que marcou uma grande época do teatro brasileiro, e cuja ausência posterior foi cruelmente sentida?

Certamente não me cabe contestar a autoridade de Schwarz crítico literário (ainda mais porque eu não vivia no Brasil, entre 1966 e 1969). Mas o que admiro em Schwarz crítico ideológico é a facilidade com que confunde critérios estéticos e critérios políticos. Adorno e Lukács parecem havê-lo feito esquecer Kant - e o Belo, aqui, só agrada em função do conceito. Assim, o filme Os Fuzis o entusiasma. Mas vale-se disso para dar alfinetadas de passagem em duas outras obrasprimas: Deus e o Diabo e Vidas Secas. E por quê? "... saio do cinema arrasado, mas não saio responsável, vi sofrimento, mas não sou culpado; não saio como beneficiário, que sou, de uma constelação de forças, de um empreendimento de exploração..." Será que a beleza do Encouraçado Potemkin se mede pelo número de vocaçðes bolchevistas que conseguiu suscitar? E a grande arte revolucionária também não procede a passo de pomba? Se não formos capazes de reconhecêlo, logo acabaremos amando as óperas da sr. Mao.

Nos seus divertidos Principios para a crítica literária ("dicionário das idéias feitas" para uso dos críticos pedantes), Schwarz repetenos sardonicamente: "Não esqueça: o marxismo é um reducionismo..."' Esta insistência era inútil: seria impossível esquecê-lo lendo você, Schwarz. Mas é verdade que a última página do ensaio nos fornece a chave de um "reducionismo" assumido, deliberada e provocadoramente. - Termino de falar longamente, diz Schwarz, da cultura brasileira. Mas, afinal, quantos indivíduos ela afeta, num país de 90 milhðes de habitantes? 50 mil, se tanto... Nada mais judicioso que esta advertência. Mas devemos acompanhar o autor nas conclusð̃es que tira? Nesta desproporção entre a cultura e a nação, vê ele uma razão a mais para proclamar alto e bom som a insignificância da "intelligentsia" - que, decididamente, nunca será mais que o "enfant terrible" da burguesia. Mas, paciência: dia virá em que esta cultura 
frívola será arrastada pelo grande maremoto. E o que pesarão os "intelectuais" na hora do Juizo Final histórico? "Que interesse terá a revolução nos intelectuais de esquerda, que eram muito mais anticapitalistas elitistas que propriamente socialistas?" Nenhum interessé, sem dúvida: da Rússia ao Cambodge, os socialismos do século XX foram certamente, parafraseando Pareto, cemitérios de "intelligentsias". Os intelectuais "deverão transformar-se, reformular as suas razōes, que entretanto havia feito deles aliados dela (da revolução)"'. $\hat{\mathrm{E}}$ isso, deverão reformular as suas razões - em "'autocriticas" cujo cerimonial é conhecido... - Certamente não é isso o que você quer, Schwarz: suspeitá-lo disto seria odioso, por um segundo que fosse. Mas confesse que, lidas em 1979, estas linhas parecem sinistras demais para não terem sido levianas em 1969, quando foram escritas. E é aqui que eu veria aflorar o preconceito que faz (ou fazia) de você o SaintJust adorniano da crítica brasileira.

Pelo menos num ponto, Roberto Schwarz é mais representativo da "intelligentsia" que fustiga do que ele pretende acreditar. Para uma parte dela, com efeito, o socialismo do século XX não é "uma idéia fora do lugar", mas "uma idéia fora de qualquer lugar". Sem dúvida, lêem e relêem os clássicos do marxismo, esmiúçam a mais não poder a teoria do valor... Mas interessam-se muito menos pela realidade histórica do marxismo no século XX, pelas suas realizações politicas e mesmo econômicas. No que se refere à documentação sobre o marxismo-leninismo existente, o Brasil é simplesmente uma ilha. Dito isto, reconheço perante os meus amigos de esquerda que, se na Paris dos anos 50 Sartre se recusava a "desanimar Billancourt" ${ }^{2}$ (proeza de que teria sido perfeitamente incapaz, por sinal), eles têm ainda mais razões para não desanimar os "favelados" e os "bóias-frias". Compreendo esta tática espontânea. Mas impressiona-me a abstração que ela confere à maior parte dos discursos sobre o "socialismo" e a "revolução". Às vezes faz acreditar que o fim hegeliano da História ocorreu... em 1916.

Uma vez assim produzido o vácuo histórico, sem dúvida pode-se continuar a empregar os aparelhos de análise marxistas como se estes fossem evidentes. Mas não é precisamente esta utilização abstrata que torna contestável a reflexão do autor sobre a insularidade da cultura no Brasil? Entre esta cultura de minoritários e a realidade nacional, seguramente são raros os pontos de contato. Já existiram, porém.

2. Billancourt: subúrbio parisiense de forte componente operária e comunista (N. da R.). 
Especialmente na década de 1960. E Schwarz toma mui justamente como exemplo a apaixonante experiência de alfabetização de Paulo Freire. Mas convence-me menos quando afirma que em 1964 "a produção intelectual começava a reorientar a sua relação com as massas". Ou ainda quando cita os grandes filmes, políticos inegavelmente, de Glauber Rocha e Nelson Pereira dos Santos. Por admiráveis que seja, estes filmes marcariam o começo de uma junção entre a produção cultural e o povo, entendido como "grande público"? ...Recordo que, ao serem lançados, os primeiros filmes de Rui Guerra ficaram apenas poucos dias em cartaz. Se forem reprisados hoje, ficarão mais tempo. Mas terão filas intermináveis?

Não sei o que Schwarz pensa atualmente desta comunicação entre a cultura e as massas, que, segundo este ensaio, teria principiado na década de 1960. Em todo caso, o seu texto dá a entender que não apenas o analfabetismo, mas também a "subcultura", poderia ser superado por um didatismo politico. Que o fosso entre o Brasil "cultivado" e o Brasil "popular" poderia ser saltado ideologicamente. E é este otimismo, implicito pelo menos, que explica, a meu entender, a dureza de Schwarz com a "intelligentsia", os sarcasmos que lança contra as cambalhotas populistas dela. Exceto em situaçס̃es-limite, diz ele, esta "intelligentsia" nunca atravessa a linha: permanece ancorada na sua classe de origem. Resta saber em que sentido se tem direito de falar numa linha de classe quando está em questão o corte cultural.

A palavra classes só pode ter aqui o sentido do século XIX - da época em que a burguesia européia considerava o proletariado como classe excluída da sociedade civil, sem ter assim sequer a dignidade de um parceiro social. Concordo que esta hierarquização, que funciona pela não-relação e pelo não-reconhecimento, ainda é feroz no Brasil. Mas coexiste com a formação de uma sociedade de classes, no sentido das sociedades ocidentais atuais. Nestas, a relação entre as classes não é mais de exclusão: por antagônicas que continuem sendo, as classes têm uma linguagem comum, um mínimo cultural comum que lhes permite negociar, concluir armisticios, exercer pressð̃es políticas (cf. o livro já clássico de Ralf Dahrendorf: Classes e conflitos de classes na sociedade industrial). O termo conflito de classe poderia assim designar no Brasil duas realidades de tipo diferente: uma vinculada ao século XIX, e, outra, ao século XX. Ora, o problema do desnivel cultural só toma sentido concreto, e trágico, contra o fundo da primeira diferença. Em outras palavras, a relação cultura/incultura recobre menos a relação exploradores/explorados que a relação desenvolvidos/subdesenvolvidos. Concedemos de bom grado que a 
manutenção desse subdesenvolvimento seja conseqüência direta de uma certa forma de exploração capitalista, mas com a condição de acrescentarmos que o subdesenvolvimento, ao criar e manter o corte cultural, faz do discurso anticapitalista da "intelligentsia" uma "vox clamantis in deserto". A situação somente se altera, e o desnivel cultural apenas começa a atenuar-se, quando a relação de castas dá lugar a uma relação de classes no sentido do século XX (por antagônicas, e mesmo por mais conscientemente antagônicas, que estas classes então possam ser).

É por isso que, no final de contas, parece-me faltar pertinência ao julgamento de Schwarz sobre os intelectuais. Certo, a "intelligentsia" opera no interior do "establishment". E dai? Sempre foi esta, pelo menos desde os Enciclopedistas, a situação paradoxal dos intelectuais" - o que não os impediu de exercer reconhecida influência sobre os movimentos reformistas ou revolucionários. Não é aí que se deve procurar o calcanhar de Aquiles da "intelligentsia". Mas, antes, na tentação do radicalismo - como observa admiravelmente Alain Besançon a propósito da "intelligentsia" russa sob a repressão czarista: "Se toda açã da sociedade civil se mostra vã, se não é possivel encontrar no Estado um parceiro, se o conflito não pode achar um quadro regular nem estabelecer as regras do jogo, torna-se tentadora $a$ atitude da grande recusa. É grande a tentação de construir um mundo imaginário que forme um substituto ideal de um mundo decretado absolutamente mau. É então que se produz uma demanda de ideologia"”3. Não parece que Besançon está-se referindo ao Brasil pós-1968?

Nestas condiçōes, a "intelligentsia" fará profissão de radicalismo político para compensar o que ela acredita ser o seu "pecado original" sociológico. Com prazer ela se deixará embriagar por um discurso messiânico, como se este pudesse anular magicamente o abismo cultural que a separa da torcida do Coríntians. E ela confiará à "Expropriação dos Expropriadores" a missão de apagar algum dia a fronteira cultural. $\mathrm{O}$ aborrecido é que existe fronteira, sem dúvida, entre uma burguesia de tipo europeu e um proletariado educado e organizado - mas entre uma casta dominante e uma massa excluída do jogo, há muito mais que fronteira: é distância sideral, é falha tectônica que é mais apropriado apontar. E sem nenhum traço de menosprezo: existe, notemos de passagem, uma certa forma de desdém de

3. A. Besançon: Les Origines intellectuelles du Iéninisme (ed. Calmann-Lévy), pp. 88-89. 
esquerda pelo Carnaval e pelo futebol que é tão intolerável como a condescendência de direita.

Assim sendo, impõe-se ao menos duas conclusões. Em primeiro lugar, nada nos garante que uma transformação revolucionária brusca seja capaz de modificar a condição cultural e a mentalidade dos "excluidos". A experiência histórica contribui muito para deixarnos céticos a esse respeito. Já que Schwarz chega a esboçar o paralelo - tão digno de interesse - entre o Brasil e a Rússia czarista, poder-seia colocar-lhe a questão: com a eliminação da oligarquia e a subversão da sociedade civil, os bolchevistas conseguiram, nestes 60 anos, assegurar a participação política do "povo"? E a sua "linguagem dura" seria o equivalente de uma cultura nova? Se a ideologia pura revelou a sua abstração, foi justamente na vitória mais prodigiosa que ela alcançou ao longo deste século...

Em segundo lugar, uma prática política só poderá ter eficácia onde a falha se transforma em fronteira. Disto se segue que toda ação cultural - ideológica ou não - , por modesta que seja, por ingênua que pareça, é de suprema importância. Já se zombou muito dos intelectuais russos que "iam ao povo". Demais até, a meu ver - pois eles tinham pelo menos o mérito de falar com o povo em vez de discorrer sobre "o povo". Pelo menos tinham o mérito de pressentir que uma politização efetiva - entendam: uma participação na polis - requeria uma comunicação mínima entre as classes, uma integração cultural minima. - Só esta expressão "integração cultural” já poderia atrair os sarcasmos de Schwarz contra mim. Pelo menos a partir de seu artigo de 1967: Vanguarda e Conformismo. Mas este artigo me parece ser tão parcial quanto é brilhante.

Que os "mass media" transformam a obra cultural em mercadoria e comercializam a produção artística - é evidente. Que então o rádio, a TV e tantos jornais contribuem para "integrar" o público... na mediocridade, quem de boa fé não concordaria? Mas o autor vai adiante. É por princípio, diz ele, que a comunicação é fraudada: toda "participação de massa" nesta "cultura" só pode fazer os usuários (os telespectadores) esquecerem que o controle dos meios de produção não lhes pertence... Não é um pouco sumário o diagnóstico? É assim tão evidente que o uso da TV nos paises capitalistas deva reduzir-se a uma mistificação?

Schwarz troça da idéia de que se possa conceber "revolução e revolução cultural como processos eletrônicos". Resta que estes “processos eletrônicos" difundem também informação - e que, quanto mais difundirem, melhor será... Sem dúvida, no regime capitalista, a 
televisão contrabandeia uma subcultura insidiosa e fraudulentamente "integradora" - e o papel dos intelectuais é denunciá-la. Mas, desde que não esteja submetida a uma censura governamental, ela também alarga o horizonte público, torna-o juiz de debates políticos, forneceIhe temas de discussão, confronta-o com as realidades de seu tempo. O que, afinal de contas, não é tão desprezivel numa época em que 900 milhð̃es de chineses puderam ser mantidos na ignorância da alunissagem dos astronautas...

A nos embrenharmos na via "ultradesmistificadora", acabaríamos, por coerência, desprezando a democratização do ensino, a pretexto de que a escola propaga "as idéias da classe dominante". Ou ainda considerando secundário o fato de que o custo dos jornais impede a maioria da população de ler um órgão diário - já que esses jornais são mercadorias rentáveis... Na verdade, a "ultradesmistificação" assenta numa ontologia social do pior - no sentido em que se fala de políticas do quanto pior melhor.

Aqui me deterei, por medo de que me suspeitem de deliciar-me secretamente com telenovelas ou até mesmo com pornochanchadas. $\mathrm{O}$ que, modestamente, eu queria indicar? Que a "consciência de classe" pressupõe um mínimo de abertura cultural, mas que isso não faz a cultura identificar-se com a ideologia - especialmente com esta que a "intelligentsia" sonha infundir àqueles que ela considera como "analfabetos politicos". E que, mais geralmente, desconhece-se a espessura e a especificidade do cultural, quando este é representado como mero tabuleiro ideológico. A reflexão crítica que vai a este extremo só pode conduzir o intelectual a pintar de vermelho sua torre de marfim, em vez de sair dela.

Não me espantaria que a saudosa Berta Dunkel tivesse deixado um texto a esse respeito, que Roberto Schwarz bem poderia editar um dia desses. Em todo caso, seria bom saber o que pensa hoje dos escritos do jovem provocador, que ele teve mil vezes razão em publicar. Talvez para acertar as contas com o passado. Mas certamente para nosso prazer. E, muitas vezes, para nossa emoção. 